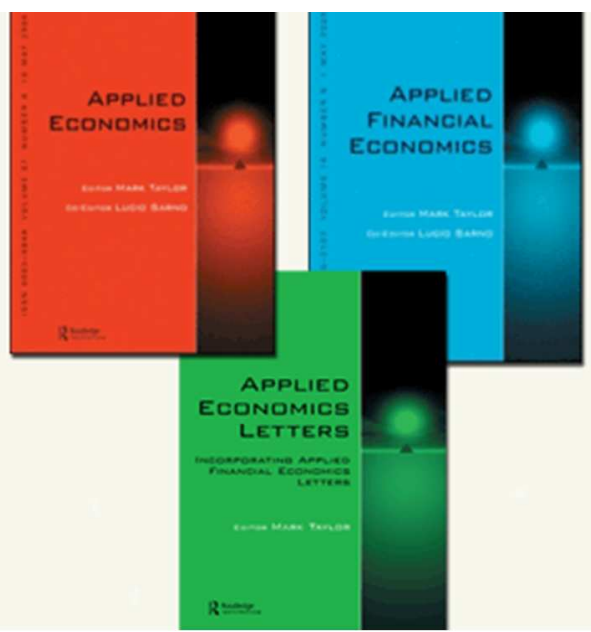

\title{
Disentangling the heterogeneous income elasticity and dynamics of health expenditure
}

\begin{tabular}{|r|l|}
\hline Journal: & Applied Economics \\
\hline Manuscript ID: & Draft \\
\hline Journal Selection: & Applied Economics \\
\hline Date Submitted by the Author: & n/a \\
\hline Complete List of Authors: & $\begin{array}{l}\text { Blazquez-Fernandez, Carla; university of cantabria, economics } \\
\text { CANTARERO, DAVID; University of Cantabria, Economics } \\
\text { Perez, Patricio; University of Cantabria, Economics }\end{array}$ \\
\hline JEL Code: & $\begin{array}{l}\text { H51 - Government Expenditures and Health < H5 - National Government } \\
\text { Expenditures and Related Policies < H - Public Economics, I10 - General }< \\
\text { Policy|Regulation/Public Health < I1 - Health < I - Health, Education, and } \\
\text { Welfare, I30 - General < I3 - Welfare and Poverty < I - Health, Education, } \\
\text { and Welfare }\end{array}$ \\
\hline Keywords: & health expenditure, income elastiticy, convergence, cluster, panel data \\
\hline \multicolumn{2}{|c}{} \\
\hline
\end{tabular}




\title{
Disentangling the income elasticity and dynamics of health expenditure
}

\begin{abstract}
In this paper, we empirically study the impact of per capita income on health care expenditure and its dynamics over time in a sample of fourteen OECD countries for the period 1971 to 2009. A simple model, built upon one developed by Newhouse (1977), suggests that health care is a necessity in the short-run but it cannot be rejected to be a luxury good in the long-run. Our findings provide strong empirical evidence that a year's health expenditure is conditioned by the previous one. Interestingly, our results reveal increasing income inelasticity over time along with huge heterogeneity across countries. Finally, this paper supports the hypothesis of conditional convergence in health care spending among countries. In designing policies which facilitate the sustainability of national health systems, we emphasize that ceteris paribus the greater the participation of public health, the lower the growth rate of health spending. Meanwhile, high share of children and elderly over working age population opposite influences. We also provide evidence that technological progress could reduce the longrun income elasticity for health care, which in turns, threaten the sustainability of health care systems.
\end{abstract}

JEL Classification: H51, I1, I18, I3 


\section{Introduction}

How much did improving income rise health care? Since Grossman (1972), there has been huge theoretical literature on health as a form of capital stock. So, the correlation between economic performance and health is one of the best-known relations in international development. Higher per capita income gives citizens greater access over many of the goods and services that promote health: nutrition, medicines, schooling, and good quality health services (Bloom and Canning, 2000). In this paper, we empirically examine the effects of income on health care spending for a sample of fourteen OECD countries, and its dynamics over 1971-2009.

Our research is closely related to a number of theoretical and empirical papers. On the theoretical side, our paper is closest in spirit to Newhouse (1977) seminal paper that high levels and growth rates of health spending may be justified by income growth. Our paper is also related to Newhouse (1992), which provides a survey of possible explanations for the rise of health spending as a share of Gross Domestic Product. In addition to rise in per capita income, he considers explanation driven by demographic changes and changes in national health policies, although Newhouse argues the bulk of the increase is attributable to technological change. This explanation has received growing attention through the last decade from health economists; for example, Jones (2004), and Hall and Jones (2007).

With respect to the empirical evidence, the open debate over the last few years pointed to the size of income elasticity over health expenditure, and whether it is greater or less than unit (Bac and Le Pen, 2002). In this regard, it should be noted from Table 1 that most studies obtained income elasticity of demand for health care around 1.1-1.4 or even more. Besides Newhouse's (1977) seminal paper, for example: Leu (1986), Parkin 
et al. (1987), Gerdtham et al. (1992a, b), Hitiris (1997), Roberts (2000), Mehrara et al. (2010), Liu et al. (2011), Hui-Kuang et al. (2011) and Woodward and Wang (2012). However, Gerdtham et al. (1998) estimated coefficients around 0.2-0.9, as was also found by Sen (2005), Chakroun (2010), Baltagi and Moscone (2010) and Farag et al. (2012).

\section{[Insert Table 1]}

Furthermore, there is a bulky of papers focused on the evolution of health care systems, based on several approaches, i.e.: intrastate or international comparisons studies, on time series or on the neoclassical growth theory, etc. Hence, Nixon (1999) supports the existence of both convergence and integration of health care expenditure in the European Union (UE) countries. Kerem et al. (2008) indicate that -although the increase of economic integration facilitates economic growth - the mere fact of the EU enlargement does not bring along an automatic homogenization of health care expenditure. Wang (2009) obtains moderate evidence of convergence in total health care expenditure - and diverse performance of the expenditure components - across the US states. Finally, Leither and Theurl (2012) find that OECD countries do not move towards a common mean and the rate of convergence is decreasing over time. Additionally, rising trends in health expenditure and explanations for health care expenditures growth differences across countries (Barros, 1998) during the last four decades had concerned about the sustainability of national health care systems (Pammolli et al., 2008). This topic had become intriguing to economic researchers, and so a growing literature has recently emerged (Chakroun, 2010; Bilgel and Tran, 2013; Kumar, 2013).

We build on this literature in three ways. First, the focus of our paper is on understanding the determinants of per capita level of health care expenditure. The 
abovementioned studies hardly distinguish between short- and long-term, nor take into account income clusters of countries and the differences in time. In this paper, our main goal will be testing for differences between short-run and long-run income elasticity, when controlling for demographic structure, the percentage of public health care expenditure over the total and technological change. A simple empirical model, built upon one developed by Newhouse (1977), provides a straightforward method for testing of on hypotheses derived from economic theory. According to a generally accepted rule, income elasticity less than unit classify health expenditure as a "necessary" good. Similarly, if elasticity is higher than unit health care will be classified as a "luxury" good. Second, we then specify a new model by allowing for health spending convergence across countries, based on the neoclassical growth theory (Barro and Salai-Martin, 1995). Third, afterwards the paper carries out diverse sensibility tests, looking at differences between subgroups of countries and subperiods of time.

When estimating the effects of income on health care spending for the period 1971 to 2009, we adopt the panel data approach. We first assume a linear and homogeneous relationship between the variables. Nonetheless, in a second stage, we also use a dynamic panel data model by applying the improved Generalized Method of Moments (GMM) by Arellano and Bover (1995) and Blundell and Bond (1998). For studying the income elasticity of health care dynamics, the full sample is split into two subperiods: the initial period (1971-1990) and the subsequent period (1991-2009). Furthermore, we divided the full sample of countries into two subgroups based on a cluster analysis for the initial observations of health care expenditure and income (that is, for year 1971). We find that health care is a necessity in the short-run, though it cannot be rejected being a luxury good in the long-run. Estimates indicate that, on average, the long-term elasticity for initial low- health expenditure and income country 
is up to $40 \%$ less than other high one. Similarly, about $80 \%$ of a year's health expenditure is conditioned by the previous one. Whereas, our findings put forward decreasing trends for the elasticity in the time period analysed, and support the hypothesis of conditional convergence. Besides, the greater the participation of public health the lower the growth rate of health spending. Meanwhile, demographic dependency generally opposite influences.

Our paper contains various innovative approaches. Firstly, as far as we are concerned, our main contributions to the existing literature consist in analysing empirically short-run versus long-run income elasticity of health care, testing for the luxury good hypothesis. In doing so, we transmit a distinction on previous contributions, as the ones by Newhouse (1977) or Sen (2005), while harmonize recent topics in health economics research. Secondly, our findings may help to explain recent outcomes by economists, viz, huge health care spending heterogeneity across countries, increasing income inelasticity over time along with threshold effect. Thirdly, from a policy economic perspective, our paper encourages the debate about implications of government's involvement for the provision of health services, and therefore on the sustainability of national health care systems.

The remainder of the paper is structured as follows. Section II provides an overview of the empirical model and a brief description of the data. Section III presents the results derived from the model. The final section summarizes and concludes.

\section{Empirical model and data}

As identified in previous section, the acknowledgeable literature on health economics has suggested income and non-income determinants are both important drivers of health 
care expenditure. So in a first step, a linear and homogeneous panel data model for health expenditure (as dependent variable to be analyzed) based on Newhouse (1977), Gerdtham (1992) and Roberts (1999) is specified. In a more formal way, our model becomes:

$$
\boldsymbol{y}_{i t}=\boldsymbol{f}\left(\mathbf{x}_{i t}, \boldsymbol{\beta}\right)+\varepsilon_{i t},
$$

where $y_{i t}$ is the natural logarithm of per capita health spending at the $t$ th observation for the $i$ th country; $f(\bullet)$ denotes health care expenditure structure; $\boldsymbol{x}_{i t}$ is the corresponding matrix of explanatory variables; $\beta$ is a vector of parameters to be estimated. The $\varepsilon_{i t}$ 's are random errors assumed to be independent and identically distributed with mean zero and variance $\sigma_{\varepsilon}^{2}$.

Previously highlighted by other researches, the preliminary estimates of the linear panel Equation 1 reveal a number of problems to deal with: i.e. residuals suffer from first-order autocorrelation and revealed group-wise heteroscedasticity. So, firstly, after initial estimates of the linear one-way fixed effect model, we use a Feasible Generalized Least Squares (FGLS) estimator, introducing temporal effects (two-way estimation), in order to prevent any possible problem. This procedure allows estimation in presence of first order autocorrelation within panels and cross-sectional correlation, and heterocedasticity across panels. Then, the general linear model can be expressed as:

$$
\boldsymbol{y}_{i t}=\boldsymbol{x}^{\prime}{ }_{i t} \boldsymbol{\beta}+\alpha_{i}+\mathrm{d}_{\mathrm{t}}+\varepsilon_{i t}
$$

where $\alpha_{i}$ is a country specific effect and $d_{t}$ is a time dummy variable. On a second step, we use a dynamic panel data approach. Specifically, the system-GMM estimator developed by Arellano and Bover (1995) and Blundell and Bond (1998) is employed. The main advantage of system-GMM lies in the fact that unlike within or between methods, it uses the estimation in levels and exploits not only the variation in data over time but also between countries. Moreover, this methodology sets additional enough 
criteria that correlations between unobserved fixed effects and explanatory variables are constant over time. System-GMM method combines the standard set of equations in first differences with suitably lagged levels as instruments. Furthermore, the ArellanoBond methodology tests for the hypothesis of absence of serial correlation and the standard errors of the estimates are robust to heteroscedasticity.

A general dynamic panel data in the first order specification from Equation 2 can be written as follows:

$$
\boldsymbol{y}_{i t}=\boldsymbol{x}_{i t}^{\prime} \boldsymbol{\beta}+\theta \boldsymbol{y}_{i, t-1}+\alpha_{i}+\boldsymbol{\varepsilon}_{i t}
$$

Note we included on the right hand side of Equation 3 the lagged dependent variable, in order to capture the inertia of health care expenditure, and to determine if there exist an "anchorage effect", that is, if the spending on a year is conditioned by the previous one or not. We now have in the equation the entire history, so any impact of $\boldsymbol{x}_{i t}$ represents the effect of new information (Greene, 2012). This paper aims to test whether health expenditure is a necessary or a luxury good. Therefore, after direct estimation of Equations 2 and 3, $\beta$ income coefficient will give short-run elasticity, while the long-run elasticity would be $\beta$ income coefficient in the long-term model. This parameter is not directly estimable, so to calculate it the estimated coefficients of the short-term model (3) are used. Then, long-run elasticity can be recovered by using:

$$
\eta \equiv \frac{\beta_{\text {income }}}{1-\theta}
$$

This paper also focuses on both possible breaks and convergence in health care expenditure between countries. Are there automatic forces that lead to convergence over time in per capita health expenditure, or whether the relative position of each country tends to stabilize over time? At some risk of oversimplifying, we interpret convergence as the possible existence of a tendency towards the reduction over time of health care 
expenditure differential between countries. This concept of convergence is the so-called sigma-convergence, measured by the standard deviation of the logarithm of the variable (De la Fuente, 2000). It does not necessary imply to withdraw inequality, but it does mean that the distribution will tend to stabilize in the long-run, provided some structural characteristics remain unchanged. These questions correspond to the concepts of absolute and conditional beta-convergence from the neoclassical growth theory (Barro and Sala-i-Martin, 1995). While it is assumed that sample countries converge to the same steady state in the former, each country converges to its own steady state in the latter. In both cases, the growth rate of health spending will be positively related to the distance that separates an economy from its steady state (Nixon, 1999).

Then, subtracting the lagged dependent variable from both sides of the Equation 3 , the dynamics of the health care expenditure for a general case yields ${ }^{1}$ :

$$
\Delta y_{i t}=x_{i t}^{\prime} \beta+(\theta-1) y_{i, t-1}+\alpha_{i}+\mathrm{d}_{\mathrm{t}}+\boldsymbol{\varepsilon}_{i t}
$$

While unconditional convergence focuses the analysis from Equation 5 on the lagged value of health expenditure, conditional convergence also considers income and other explanatory variables. Next, we explore the dynamics of these in terms of the impact of per capita health care level on the evolution of the relative expenditure of two countries.

On the one hand, if $\theta<1$ the coefficient of the lagged variable $(\theta-1)<0$, then growth rate of health care falls with the expenditure level and this implies that per capita health care expenditure tends to converge across countries. On the other hand, if $\theta>1$ it follows that $(\theta-1)>0$, so the growth rate of health care increases with the level of expenditure, and per capita health care expenditure across countries increases without bounce.

${ }^{1}$ Again, we use a FGLS estimator introducing temporal effects. 
Basic data used in this analysis are taken from the OECD Health Data (2012), the main and largest available source of information to compare health care systems ${ }^{2}$. Empirical results are based on a balanced panel dataset for fourteen countries over the period 1971-2009: Australia, Austria, Canada, Finland, Iceland, Ireland, Japan, New Zealand, Norway, Portugal, Spain, Sweden, United Kingdom and the United States. The benefits of using a balanced panel data set consist in that it allows doing the analysis of stationarity of the variables. Most of the tests require that the panels be strongly balanced.

In this paper, we consider as dependent variable the log of per capita health care expenditure (expenditure), expressed in \$US purchasing power parities (PPP). The list of explanatory variables is based on data availability for a balanced panel and they were used by knowledgeable scholars (i.e.: Baltagui and Moscone, 2010) ${ }^{3}$. It includes first the lagged dependent variable (expenditure t $-1_{1}$ ) to account for the anchorage effect. Second, the log of PPP per capita GDP (income) to analyze the income elasticity of health care expenditure. As shown in Fig. 1, similar increases in health expenditure could be observed through our country sample. Third, a ratio of demographic dependency (dependency) to capture the impact that the proportion of children and elderly have on health expenditure ${ }^{4}$. It is expected that young and old people use more health care services than working age population. Hence, Alemayehu and Warner (2004) estimate the magnitude and age distribution of lifetime health care expenditures;

2 OECD Health Data allows doing benchmarking and international comparisons of different health systems. Additionally both, its frequency (renewable annually) and that it is used in a wide range of academic papers, support the reliability of its utilisation.

${ }^{3}$ These are some of the reasons for using these explanatory variables despite other (i.e.: lifestyles or supply side variables) in our model.

${ }^{4}$ By definition, the dependency ratio is the relationship between the age population potentially dependent between the potentially active age population. There are three main ways to calculate it: i) "total dependency ratio" (defined as the population aged 0-14 and the population aged over 65 divided by the working age population), which is considered in this paper; ii) "dependency ratio of young" (defined as the population aged 0-14 divided by the working age population); and iii) "dependency ratio of older" (defined as the population aged over 65 divided by the working age population). 
in this regard, Jones (2004) reflects the fact that people at a given level of live expectancy suffer from more severe, and costly, medical problems. Four, the percentage of public health care expenditure over the total (public share) that stands for health policies $^{5}$. Could public and private choices on health care affect total health care expenditures? Newhouse (1992) speculates that the spread of insurance has steadily reduced price for consumer and so driven up demand for medical services. Finally a temporal trend is included, in order to proxy for unobserved factors linked to technology (including new health technologies) and to check for the sensitivity of the results to specification problems (technology). In this respect, Newhouse (1992) points out that technological change means not only new types of physical capital, but also new procedures; that is what he calls "the march of science and the increased capabilities of medicine". Table 2 presents the details concerning the definitions and sources of the variables.

\section{[Insert Fig. 1]}

[Insert Table 2]

\section{Results}

In this section we present the results from the estimation of the panel data models, controlling for various periods of time and different samples of countries, although before we proceed to perform some preliminary tests. Given that our empirical study is based on a time-series cross-country panel data, we first analyze all variables within

\footnotetext{
${ }^{5}$ Countries can choose different types of funding: public, private, or a combination of both. Considering that the degree of health decentralization of each country is linked to the political constraints and with the type of model (Social Security or National Health System) valid in each case, it should be noted that the greater degree of decentralization takes place in essentially private models. Then, depending on whom got health powers, resources will be got by different ways, and may be taxes will be one of the most important ways to slow the growth of national health expenditures (Baicker and Skinner, 2011).
} 
Equations 2 and 3 to ensure that there aren't spurious regressions in our estimates. With this aim, various unit root tests for panel data that consider non-stationary series under the null hypothesis are carried out. Firstly, we perform first generation of panel unit root tests (which do not take into account cross-country dependence). In this regard, LevinLin-Chu (2002), and Im-Pesharan-Shin (2003) on the annual data indicate all variables were stationary (public share is the exception). However, a common feature of these econometric tests is that they suffer from loss of power when individual specific trends are included (Baltagi, 2008). So we carry out the Breitung (2000) test that indicates the hypothesis that all variables are unit root is never rejected.

Secondly, Pesaran (2007) second generation CIPS test (which assumes crosssection dependence) are reported in Table 3. We present results for lag orders $p=0,1,2$ and 3, finding that in most cases variables are nonstationary. We then apply panel cointegration tests due to Westerlund (2007), for fourteen series and three covariates. Tests reveal the null cannot be rejected at conventional levels ${ }^{6}$. To sum up, the general picture emerging from this strand of hypothesis tests supports the argument for a balanced relationship between variables in the long-run, which guarantee for the stable equilibrium of the model. It is known that when the series are integrated of the same order, they are cointegrated.

\section{[Insert Table 3]}

\section{Elasticity across countries}

We now examine the effect of income and other explanatory variables on health expenditure, using OECD data for fourteen countries over the period 1971-2009. Table

\footnotetext{
${ }^{6} \mathrm{Pt}=-9.90$ and $\mathrm{Pa}=-26.35$ support the null that the whole panel is cointegrated, whereas $\mathrm{Gt}=-3.03$ and $\mathrm{Ga}=-31.34$ also support that at least one of the panel units presents cointegration.
} 
4 contains estimation results based on the FGLS estimates from Equation 2, which are highly significant with expected signs in most of the explanatory variables. Income elasticity of health expenditure around 0.9 suggests health should be classified as a necessary $\operatorname{good}^{7}$ although it should be considered with caution in column (iii). These results are robust to the inclusion of other variables. On the one hand, the coefficient on the dependency ratio is statistically significant and exerts a positive influence on health care expenditure. It is expected that young and old people use more health care services than working age population. In fact, both variables have been separately identified by the literature as having a role in determining health care expenditures (Baltagi and Moscone, 2010). On the other hand, the estimated coefficient on public share is also significant with a negative sing. That is, countries with higher share of public expenditures should have lower per capita health spending. It should be noted, however, that Baltagi and Moscone (2010) obtain coefficients are not statistically significant.

\section{[Insert Table 4]}

Table 5 reports the estimates from the dynamic panel data Equation 3. We present results for both, without and with technical progress, in Panels A and B respectively. Our findings support the null that health care is a necessity good in the short-run, as income elasticity around 0.2 is largely smaller than in the linear model. However, the long-run income elasticity from Equation 4 grows sharply and differs between panels. Note when the technology progress is omitted (Panel A) coefficient on long-run elasticity exceeds the unity, and so health care seems to be a luxury good. Otherwise, it remains smaller than unit and health care should be classified as a necessary good. Note, the 1.0 rule has limitations, especially when elasticities of 0.2 and 0.9 are both classified as "necessities"; these numbers are economically and statistically

\footnotetext{
${ }^{7}$ Confidence interval at $95 \%$ ranges from 0.83 to 1.06 . So, if the classification rule is based upon comparison to 1.0 , statistically strictly the statement could be incorrect.
} 
quite different. Both dependency and public share variables are insignificant, and these findings accord with previous studies on the OECD countries (Baltagi and Moscone, 2010). The estimated coefficient on the technology imply a significant positive effect (Panel B), which correspond to the impact of technical progress on health care expenditure over years. It is also noteworthy that lagged dependent variable is always positive and significant. Coefficient on the lagged dependent variable is less than one in absolute terms to guarantee the stability of the model. So a year's health expenditure is conditioned at $80 \%$ by the one from previous year, despite the presence of explanatory variables that represent the effect of new information. This confirms the existence of anchorage effect, which means that health expenditure is likely to change in a slowly way over the years. In sum, the estimated short-run and long-run elasticities are correctly signed in our preferred specification (iii). Furthermore, both the size and the significance are remarkable stable in all of the alternative specifications.

\section{[Insert Table 5]}

Now we briefly discuss the robustness of the results presented above. Concretely, we check the sensitivity of the estimates to income and health spending heterogeneity in the sample of OECD countries used in our empirical analysis, and also to alternative definitions of the sample time. Economic and social heterogeneity across countries, despite the ongoing process of global integration, was far from being negligible in the period under analysis (López-Bazo et al., 2004). The empirical model previously estimated imposes common effects for all the countries in the sample.

Firstly, we find out about health care differences over time. As shown by Carrion-i-Silvestre (2005), the debate about health care expenditure should be addressed taking into account structural breaks, if not the estimation of the parameters could be biased. Thus, we initially analyze the existence of possible trend breaks for per capita 
health expenditure, over the period under analysis. Based on recent papers focused on testing for structural breaks in panel data models (i.e.: Liu et al., 2011) —and from a graphic outlook in order to homogenize the evolution for the 14 countries-, we split the sample time into four subperiods: 1971-1975, 1976-1991, 1992-2001 and 20022009 (Fig. A.1 and Table A.1 in the Appendix) ${ }^{8}$. Afterwards, to give greater statistical reliability to the estimates, we only consider two long periods: 1971-1990 and 19912009. Table 6 reports the results for income elasticity of health expenditure when performing our preferred specification (iii). This is the most complete, and therefore the sensitivity analysis is focused on it. There, we primary reproduce equation (iii) from Table 5. We found, first, the smaller the sample period, the greater the elasticity; and second, when taking into account technical progress, elasticity seems to be somewhat higher in the former period (1971-1990) than in the latter one (1991-2009) 9

Secondly, we deal with heterogeneity across countries. As noted above in the empirical model and data section, in specifying the regression models (2)-(3) we assumed that its specifications applied to all the observations. This is likely not true for some of the countries in our sample, suggesting possible omitted variable bias in the estimation results discussed above. To test for the significance of these bias, we split the sample of countries into two groups based on a cluster analysis for the initial observations of health care expenditure and income (that is, for year 1971). The uppergroup (higher initial levels of expenditure and income) consist of: Australia, Austria, Canada, Finland, Iceland, New Zealand, Sweden, United Kingdom and the United States. Meanwhile, the lower-group (lower initial levels of expenditure and income) consist of: Ireland, Japan, Norway, Portugal and Spain. Based on the estimates, Table 6 reports the average income elasticity of per capita health care expenditure, which seems

\footnotetext{
${ }^{8}$ This type of subdivisions is common in growth processes for Western economies.

${ }^{9}$ It should be noted that estimates take into account all the regressors, which vary across the estimations. Then, it could explain for instance that both sub-sample estimates are higher than in the complete one.
} 
to be higher in the upper-economies. Here, when technical progress is included, the estimated coefficient on the average long-run elasticity is about unit, compared with an average elasticity for the lower-countries of 0.62 . So, long-term elasticity for a lowercountry is up to $40 \%$ less than for an upper-one. That is, spending on health care seems to be a need among the lower-countries and a luxury in the upper-group. Then, this may indicate the existence of a threshold effect, from which income elasticity increases. Average elasticities of this size are plausible on a priori grounds, i.e.: OECD (2011) supports richer countries spend more in health goods than the poorer ones.

\section{[Insert Table 6]}

Dynamics of health care expenditure

One approach to assess stability is to study whether health care elasticity has changed as time goes on. Firstly, starting with a sample of 15 years from 1971 to 1985, Equation 3 is estimated recursively by adding one extra observation at a time up to 2009. Fig. 2 plots the results from the recursive estimates for the full sample observations. When assuming non-technical progress, long-term elasticity does not show any trend, and its values seem to converge to 1.1 . Short-term elasticity initially presents a downward trend though its values are very close to a quarter since 1991, and these results agree with FGLS estimates. However, in the more likely scenario of technical progress, elasticity shows decreasing trends in both the short- and long-term, even below one in the longrun.

\section{[Insert Fig. 2]}

Secondly, should the downward trend for the elasticity observed in Fig. 3, when assuming technical progress, be interpreted as evidence towards a greater concern in 
health care? There are several reasons that could be responsible for the downward trend. First, as the sample size time increases from 15 to 39 observations elasticity converges to the long-run values. Second, the long-run elasticity from Equation 4 falls because the coefficient on income (numerator of the statistic) is reduced over time, while the coefficient on the lagged variable (in the denominator) remains broadly stable. Third, drops of the coefficient on income occurred primarily among lower-countries whereas it was less dramatic in initially upper-countries, if any.

\section{[Insert Fig. 3]}

Thirdly, the specifications discussed above focus on income and do not include a variable to represent the scope of less developed countries to catch-up to the health care levels prevailing in the industrial countries. To this end, we carry out two approaches rooted on the traditional concept of economic convergence from the neoclassical growth theory (Barro and Sala-i-Martin, 1995). They were recently considered for health care expenditure in Nixon (1999), Kerem et al. (2008), Wang (2009) or Leiter and Theurl (2012). Fig. 4 provides evidence to support sigma-convergence. The level of inequality fell sharply early years, was stabilized after the second half of the $70 \mathrm{~s}$, and continued to fall gently into the 90 s and 2000 . Over the period as a whole the statistic falls by approximately two thirds, from 0.10 in 1971 to 0.03 in 2009 .

\section{[Insert Fig. 4]}

On a second step we conducted the analysis for beta-convergence from Equation 5 , in which the dependent variable is the growth rate of per capita health care expenditure. Table 7 shows estimates for unconditional convergence regressions in the first column, and conditioning for income and other explanatory variables in successive columns. In the absence of the conditioning variables for the full set of observations, the rate of convergence was estimated to be the traditional $2 \%$ per year. Fig. 5 plots the 
inverse relation between the average growth rate from 1971 to 2009 vs. health expenditure in 1971 (initial year). It indicates that health care spending tends to grow faster between initially lower-economies, though the process of convergence is very slow. Nonetheless, it is interesting to note that when controlling for possible differences across national steady state the rate of convergence rose to $9 \%$, and countries converged rapidly to the same spending pattern. Another interesting finding is that the coefficient on the share of public health expenditure becomes negative and significant at conventional levels. Indeed, the coefficient on income is significantly positive in all specifications.

\section{[Insert Fig. 5]}

Table 7 also deals with convergence across samples of countries. To check for different patterns of convergence, we used the two groups of countries previously defined, that is, the lower- and upper-groups of countries and estimate the counterpart of Equation 5. Perhaps not surprisingly, it should be stressed how estimates show marked instability over the period 1971-2009. On the one hand, the rate of convergence ranges from $9 \%$, in the upper-group, to $13 \%$ for the lower-one. On the other, dependency ratio becomes significant positive for the latter, but not for the former. This finding is likely due to ageing population of countries like Japan, Portugal and Spain. Finally, the estimated coefficient on public share for the period 1991-2009 reflects the tendency of the originally lower-countries to develop public health systems, and therefore to experience relatively lower growth of health care spending. Note the coefficient on public health care expenditure for lower-countries over the period 19912009 is near four folds the one for upper-countries (i.e. -0.009 vs. -0.34). Therefore, growth rates pick up changes in relative social and institutional issues.

[Insert Table 7] 


\section{Conclusions}

The results found in this study for a sample of 14 OECD countries over the period 1971-2009 support the hypothesis that health care is a necessity in the short-run, though it cannot be strongly rejected to be a luxury good in the long-run. In this respect, the evidence put forward reveals substantial territorial variations in the effect of income and socioeconomic characteristics, when controlling by initial levels of both per capita income and health expenditure. In particular, we find that long-term income elasticity across the lower-countries is, on average, up to $40 \%$ less than the obtained between the upper-ones. These findings ultimately imply that spending on health care should always be a need for lower-countries, even in the long-term, and thus the need of covering costs of living becomes more complex the higher the income (threshold effect).

Also, our results indicate that about $80 \%$ of a year's health expenditure is conditioned by the previous one despite the presence of other explanatory variables. The anchorage effect might be behind the features observed, and already reported in the recent literature, about the sustainability of national health care systems. This would be due, everything else being equal, the fact that national health expenditures are likely to change in a very slowly way over the years.

Both, initial health expenditure-income clusters and temporal breakdown, suggest that income elasticity should lead that national standards of health care spending converge in the long-run. However, other socioeconomic characteristics as the forms - public or private - of supply health services reflect the tendency of the originally lower-countries to develop public health systems, and therefore to experience significant lower growth of health care spending than the upper-ones. Demographic dependency generally opposite influences. 
From a policy economic perspective, rising trends in health expenditure had concerned about the sustainability of national health care systems. However, our results confirm that nowadays same health policies can have different effects, depending on the framework in which it is implemented. For example, public health expenditure cuts could increase private health expenditure (related with income) with an indeterminate effect on total health expenditure. The evidence for a diverse sample of countries suggests that when controlling for the baseline, public participation might be significant for limiting the growth of health spending. Similarly, there is also evidence that greater health expenditures do not unavoidably reverse in health outputs improvements. On the one hand, spending on health care seems to be increasingly decoupled from income changes between some countries. On the other, if cuts are in necessary investments there will be significant health spending increases over the long-run (OECD, 2010 and 2012).

Finally, it is worth stressing, from an economic point of view, that technological innovation, while enabling extraordinary achievements in improving health, exerts additional pressure on health spending by introducing drugs and high-cost techniques in the OECD countries. Technological change has significantly shifted out the frontier medical condition that can be treated (Jones, 2004; García and Manrique, 2012). Consequently, a cost-effectiveness analysis for health care expenditures should be done.

\section{References}

Alemayehu, B., and Warner, K.E. (2004) The lifetime distribution of health care costs, Health Services Research, 39, 627-642. 
Arellano, M., and Bover, O. (1995) Another look at the instrumental variable estimation of error-components models, Journal of Econometrics, 68, 29-51.

Bac, C., and Le Pen, Y. (2002) An international comparison of health expenditure determinants, in 10th International Conference on Panel Data, Berlin, July 5-6, 2002 from International Conferences on Panel Data.

Baicker, K., and Skinner, J.S. (2011) Health care spending growth and the future of U.S. Tax Rates. NBER Working Paper No. 16772.

Baltagui, B.H. (2008) Econometric Analysis of Panel Data, Wiley, John and Sons.

Balgati, B.H., and Moscone, F. (2010) Health care expenditure and income in the OECD reconsidered: evidence from panel data, Economic Modelling, 27, 804811.

Barro, R.J. and Sala-i-Martin, X. (1995) Economic Growth. McGraw Hill.

Barros, P.P. (1998) The black box of health care expenditure growth determinants, Health Economics, 7, 639-694.

Bilgel, F. and Tran, K.C. (2013) The determinants of Canadian provincial health expenditures: evidence from a dynamic panel, Applied Economics, 45, 201-212.

Bloom, D. E., and Canning, D. (2000) The health and wealth of nations, Science, 287, 1207-1209.

Blundell, R., and Bond, S. (1998) Initial conditions and moment restrictions in dynamic panel data models, Journal of Econometrics, 87, 115-143.

Breitung, J. (2000) The local power of some unit root tests for panel data, in Advances in Econometrics, Volume 15: Nonstationary Panels, Panel Cointegration, and Dynamic Panels, ed. B. H. Baltagi, 161-178. Amsterdam: JAI Press.

Carrion-i-Silvestre, J.L. (2005) Health care expenditure and GDP: Are they broken stationary?, Journal of Health Economics, 24, 839-854. 
Chakroun, M. (2010) Health care expenditure and GDP: an international panel smooth transition approach, International Journal of Economics, 4, 189-200.

De la Fuente, A. (2000) Convergence across countries and regions: Theory and Empirics, CEPR Discussion Papers No. 2465.

Farag, M., Nandakumar, A.K., Wallack, S., Hodgkin, D., Gaumer, G. and Erbil, C. (2012) The income elasticity of health care spending in developing and developed countries, International Journal of Health Care Finance and Economics, 12, 145-162.

García, P., and Manrique, M. (2012) Estrategias de reforma de los sistemas sanitarios en la UEM, Economic Bulletin November Banco de España, 67-80.

Gerdtham, U.G. (1992) Pooling international health expenditure data, Health Economics, 1, 217-231.

Gerdtham, U.G., Sogaard, J., Andersson, F., and Jonsson, B. (1992a) An econometric analysis of health care expenditure: a cross-section of OECD countries, Journal of Health Economics, 11, 63-84.

Gerdtham, U.G., Sogaard, J., Andersson, F., and Jonsson, B. (1992b) A pooled crosssection analysis of the health care expenditure of the OECD countries, in Health Economics World Wide, Zweifel, P., Frec., H.E. (eds.), Kluwer Academic Publishers, Dordrecht.

Gerdtham, U.G., Jonsson, B., Macfarlan, M., and Oxley, H. (1998) The determinants of health expenditure in the OECD countries, in Health, The Medical Profession and Regulation, Zweifel, P. (ed.): Kluwer Academic Publishers, Dordrecht.

Greene, W.H. (2012) Econometric Analysis, Pearson Education, Upper Saddle River (New Jersey). 
Grossman, M. (1972) On the Concept of Health Capital and the Demand for Health, Journal of Political Economy, 80, 223-255.

Hall, R.E. and Jones, C.I. (2007) The Value of live and the rise of health spending, Quarterly Journal of Economics, 122, 39-72.

Hitiris, T. (1997) Health care expenditure and integration in the countries of the European Union, Applied Economics, 29, 1-6.

Hui-Kuang, T., Wang, D., and Chang, L-Y. (2011) Examining the heterogeneous effect of healthcare expenditure determinants, International Journal of Behavioural and Healthcare Research, 2, 205-213.

Im, K.S., Pesaran, M.H., and Shin, Y. (2003) Testing for unit roots in heterogeneous panels, Journal of Econometrics, 115, 53-74.

Jones, C.I. (2004) Why have health expenditure as a share of GDP risen so much? U.C. Berkeley working papers (a revision of NBER Working Paper No. 9325).

Kerem, K., Puss, T., and Maldre, R. (2008) Health and convergence of health care expenditure in EU, International Business and Economics Research Journal, 2, $29-43$.

Kumar, S. (2013) Systems GMM estimates of the health care spending and GDP relationship: a note, European Journal of Health Economics, 12, 503-506.

Leiter, A., and M., Theurl, E. (2012) The convergence of health care financing structures: empirical evidence from OECD-countries, European Journal of Health Economics, 13, 7-18.

Leu, R.E. (1986) The public-private mix and international health care costs, in Public and Private Health Services, Culyer, A.J., Jonsson, B. (Eds.), Basil Blackwell, Oxford. 
Levin, A., Lin, C-F., and Chu, C-S. (2002) Unit root tests in panel data: Asymptotic and finite-sample properties, Journal of Econometrics, 108, 1-24.

Liu, D., Li, R., and Wang, Z. (2011) Testing for structural breaks in panel varying coefficient models: with an application to OECD health expenditure, Empirical Economics, 40, 95-118.

López-Bazo, E., Vayá, E., and Artís, M. (2004) Regional externalities and growth: evidence from European regions, Journal of Regional Science, 41, 43-73.

Mehrara, M., Musai, M., and Amiri, H., (2010) The relationship between health expenditure and GDP in OECD countries using PSTR, European Journal of Economics Finance and Administrative Sciences, 24, 1450-2275.

Newhouse, J.P. (1977) Medical care expenditure: a cross-national survey, The Journal of Human Resources, 12, 115-125.

Newhouse, J.P. (1992) Medical care costs: how much welfare loss?, Journal of Economic Perspectives, 6, 3-21.

Nixon J. (1999) Convergence analysis of health care expenditure in the EU countries using two approaches, Discussion Papers in Economics No. 3, The University of York.

OECD Health Ministerial Meeting (2010) Health system priorities when money is tight, Session 1, Paris, 7-8 October 2010.

OECD indicators: Health at a Glance (2011). Paris: OECD.

OECD (2012) Health at a Glance: Europe 2012. Paris: OECD.

OECD (2012): OECD Health Data File 2012.

Pammolli, F., Riccaboni, M., and Magazzini, L. (2008) The sustainability of European health care systems: beyond income and aging, European Journal of Health Economics, 13, 623-634. 
Parkin, D., McGuire, A., and Yule, B. (1987) Aggregate health care expenditures and national income, Journal of Health Economics, 6, 109-127.

Pesaran, M. H. (2007) A simple panel unit root test in the presence of cross section dependence, Journal of Applied Econometrics, 22, 265-312.

Roberts, J. (1999) Sensitivity of elasticity estimates for OECD health care spending: analysis of a dynamic heterogeneous data field, Health Economics and Econometrics, 8, 459-472.

Roberts, J. (2000) Spurious regression problems in the determinants of health care expenditures: comment on Hitiris (1997), Applied Economics, 7, 279-283.

Sen, A. (2005) Is health care a luxury?, International Journal of Health Care Finance and Economics, 5, 147-164.

Wang, Z. (2009) The convergence of health care expenditure in the US States, Health Economics, 18, 55-70.

Westerlund, J. (2007) Testing for error correction in panel data, Oxford Bulletin of Economics and Statistics, 69, 709-748.

Woodward, R.S., and Wang, L. (2012) The oh-so straight and narrow path: can the health care expenditure curve be bent?, Health Economics, 21, 883-1036. 
Figures and Tables

Table 1. A summary survey of previous studies on national health care expenditure

\begin{tabular}{|c|c|c|c|c|}
\hline REFERENCE & CROSS-SECTIONS & TIME-PERIOD & METHODOLOGY & $\begin{array}{c}\text { INCOME } \\
\text { ELASTICITY }\end{array}$ \\
\hline Newhouse (1977) & 13 developed countries & 1970 & Cross section. & $1.15-1.31$ \\
\hline Leu (1986) & 19 OECD countries & 1974 & Cross section. & $1.18-1.36$ \\
\hline Parkin et al. (1987) & 18 OECD countries & 1980 & Cross section. & $1.12-1.18$ \\
\hline $\begin{array}{l}\text { Gerdtham et al. (1992 } \\
\text { a and b) }\end{array}$ & 19 OECD countries & 1987 & Cross section. & 1.33 \\
\hline Hitiris (1997) & 10 OECD countries & $1960-1991$ & Panel Data. & $1.14-1.17$ \\
\hline $\begin{array}{l}\text { Gerdtham et al. } \\
\text { (1998) }\end{array}$ & 22 OECD countries & $1970-1991$ & Panel Data. & 0.74 \\
\hline Roberts (2000) & 10 European countries & $1960-1993$ & $\begin{array}{l}\text { Hitiris replicated } \\
\text { model (1997). }\end{array}$ & 1.00 \\
\hline Sen (2005) & 15 OECD countries & $1990-1998$ & Panel data. & $0.21-0.51$ \\
\hline Chakroun (2010) & 17 OECD countries & $1975-2003$ & $\begin{array}{l}\text { Multivariate } \\
\text { regression model. }\end{array}$ & $0.70-0.90$ \\
\hline $\begin{array}{l}\text { Baltagi and Moscone } \\
(2010)\end{array}$ & 20 OECD countries & 1971-2004 & Panel data. & $0.45-0.90$ \\
\hline Mehrara et al. (2010) & 16 OECD countries & $1993-2007$ & Panel data. & 2.59 \\
\hline Liu et al. (2011) & 22 OECD countries & $1960-2002$ & $\begin{array}{l}\text { Semiparametric } \\
\text { panel varying } \\
\text { coefficient model. }\end{array}$ & 1.60 \\
\hline $\begin{array}{l}\text { Hui-Kuang et al. } \\
\text { (2011) }\end{array}$ & $\begin{array}{l}25 \text { countries: Taiwan and } \\
24 \text { OECD countries }\end{array}$ & $1992-2007$ & Quantile regressions. & $1.20-1.47$ \\
\hline $\begin{array}{l}\text { Woodward and Wang } \\
\text { (2012) }\end{array}$ & United States & $1960-2008$ & Time series. & 1.39 \\
\hline Farag et al. (2012) & $\begin{array}{l}173 \text { developing and } \\
\text { developed countries }\end{array}$ & $1995-2006$ & Panel data. & $0.82-0.90$ \\
\hline
\end{tabular}


Fig. 1. Per capita health expenditure vs. income, 1971 and 2009

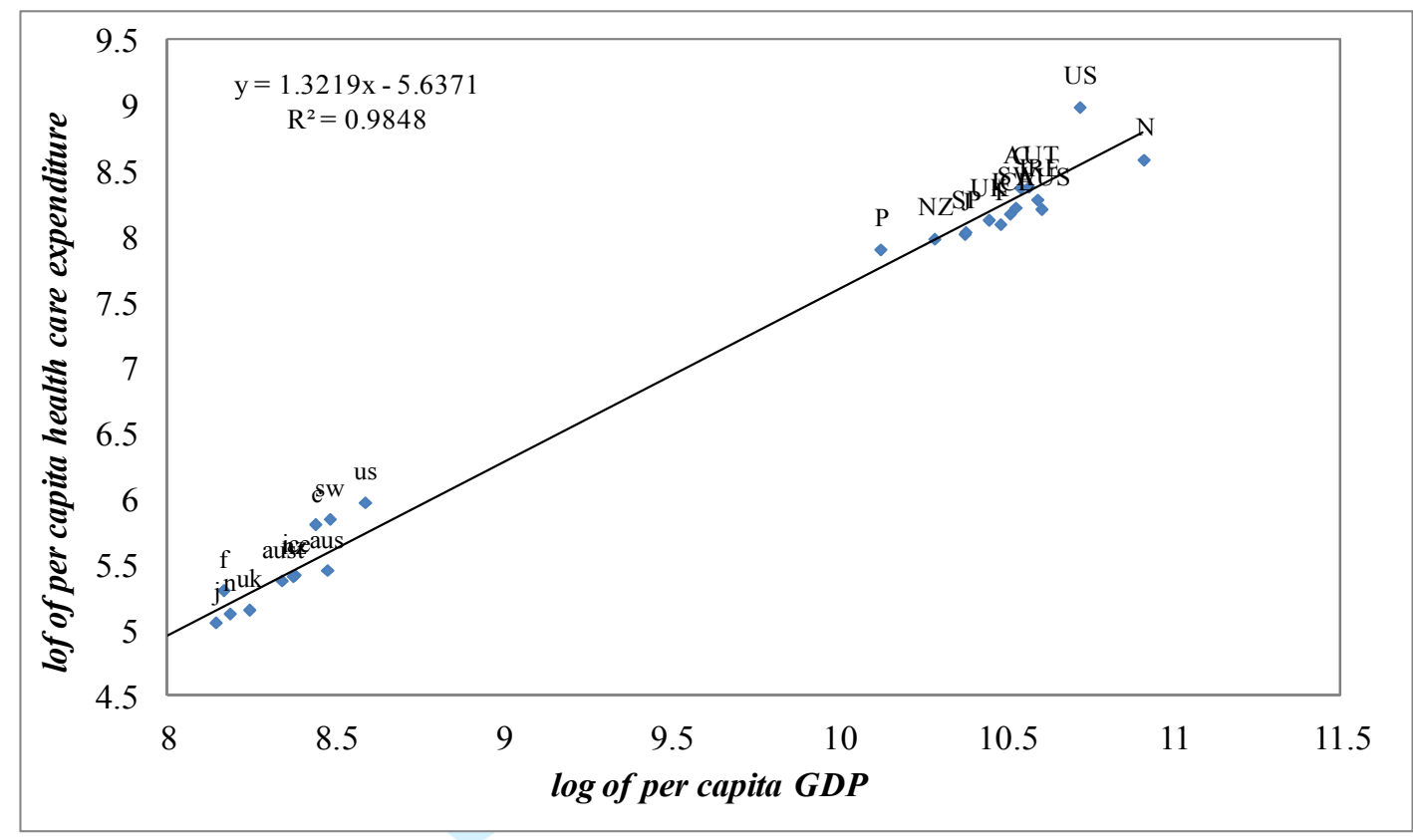

Notes: Australia(aus), Austria(aust), Canada(c), Finland(f), Iceland(ice), Ireland(ire), Japan(j), New Zealand(nz), Norway(n), Portugal(p), Spain(sp), Sweden(sw), United Kingdom(uk) and the United States(us). Abbreviations of the countries in lowercase letters refer to data for 1971, while those in capital letters are for the year 2009. 
Table 2. Variables and data sources

\begin{tabular}{|c|c|c|}
\hline Variable & Definition & Data Source \\
\hline expenditure & $\begin{array}{l}\text { Per capita total health care expenditure. Expressed in \$US } \\
\text { Purchasing Power Parities (PPP) and natural logarithms. }\end{array}$ & OECD Health Data (2012). \\
\hline income & $\begin{array}{l}\text { Per capita Gross Domestic Product. Expressed in \$US PPP } \\
\text { and natural logarithms. }\end{array}$ & OECD Health Data (2012). \\
\hline dependency & $\begin{array}{l}\text { Dependency ratio defined as the population aged } 0-14 \text { and } \\
\text { the population aged over } 65 \text { divided by the working age } \\
\text { population. }\end{array}$ & $\begin{array}{l}\text { Authors' elaboration based in } \\
\text { OECD Health Data (2012). }\end{array}$ \\
\hline public share & $\begin{array}{l}\text { Public health care expenditure as percentage of total health } \\
\text { expenditures. }\end{array}$ & OECD Health Data (2012). \\
\hline technology & $\begin{array}{l}\text { A temporal trend, in order to proxy for unobserved factors } \\
\text { linked to technology (including new health technologies). }\end{array}$ & Authors' elaboration. \\
\hline
\end{tabular}


Table 3. Second generation CIPS test: Pesaran (2007)

\begin{tabular}{|c|c|c|c|c|c|c|c|c|}
\hline \multirow{3}{*}{ Variable } & \multicolumn{8}{|c|}{ INTERCEPT ONLY } \\
\hline & \multicolumn{8}{|c|}{ number of lags } \\
\hline & \multicolumn{2}{|l|}{0} & \multicolumn{2}{|l|}{1} & \multicolumn{2}{|l|}{2} & \multicolumn{2}{|l|}{3} \\
\hline \multirow{4}{*}{$\begin{array}{l}\text { expenditure } \\
\text { income } \\
\text { dependency } \\
\text { public share }\end{array}$} & \multicolumn{2}{|l|}{-1.97} & \multicolumn{2}{|l|}{-1.91} & \multicolumn{2}{|l|}{-1.99} & \multicolumn{2}{|l|}{-2.13} \\
\hline & \multicolumn{2}{|l|}{-1.49} & -1.90 & & \multicolumn{2}{|l|}{-1.83} & \multicolumn{2}{|l|}{-1.69} \\
\hline & -1.58 & & -3.13 & *** & \multicolumn{2}{|c|}{$-2.68^{* *}$} & \multicolumn{2}{|c|}{$-2.52^{* * *}$} \\
\hline & \multicolumn{2}{|c|}{$-2.20^{* *}$} & 2.19 & ** & \multicolumn{2}{|c|}{$-2.38^{* * *}$} & \multicolumn{2}{|l|}{-2.45} \\
\hline \multirow{3}{*}{ Variable } & \multicolumn{8}{|c|}{ INTERCEPT and TREND } \\
\hline & \multicolumn{8}{|c|}{ number of lags } \\
\hline & \multicolumn{2}{|l|}{0} & 1 & & \multicolumn{2}{|l|}{2} & \multicolumn{2}{|l|}{3} \\
\hline expenditure & \multicolumn{2}{|l|}{-2.87} & 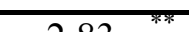 & & \multicolumn{2}{|l|}{-2.66} & \multicolumn{2}{|l|}{-2.42} \\
\hline income & \multicolumn{2}{|l|}{-2.12} & \multicolumn{2}{|c|}{$-2.66^{*}$} & \multicolumn{2}{|l|}{-2.30} & \multicolumn{2}{|l|}{-2.07} \\
\hline dependency & -1.20 & & -3.16 & *** & -2.79 & ** & -2.38 & \\
\hline public share & -2.81 & $* *$ & -2.59 & & -2.72 & $* *$ & -2.76 & ** \\
\hline
\end{tabular}

Notes: Null hypothesis CIPS: series are I(1).

${ }^{* * *}, * *$, and ${ }^{*}$ denote significant at $1 \%, 5 \%$, and $10 \%$. 
Table 4. Estimation of the health care expenditure from the linear model Dependent variable: expenditure

\begin{tabular}{|l|r|r|r|}
\hline Variable / Specification & (i) & (ii) & \multicolumn{1}{|c|}{ (iii) } \\
\hline \multirow{2}{*}{ income } & $0.87^{* * * *}$ & $0.86^{* * *}$ & 0.94 \\
& $(0.06)$ & $(0.06)^{* * *}$ & $(0.06)^{* *}$ \\
dependency & & $0.44^{* *}$ & $0.53^{* *}$ \\
& & $(0.23)$ & $(0.22)^{* * *}$ \\
public share & & & $-0.32^{* *}$ \\
\hline Wald chi2 & & & $(0.08)$ \\
Prob $>_{\text {chi2 }}$ & 8039.84 & 7808.31 & 8441.26 \\
\hline AR(1) coefficient & 0.00 & 0.00 & 0.00 \\
\hline
\end{tabular}

Notes: Standard errors are reported in brackets. Number of observations: 546. ${ }^{* * *},{ }^{* *}$, and ${ }^{*}$ denote significant at $1 \%, 5 \%$, and $10 \%$. Coefficient on income yields the short-run elasticity. 
Table 5. Estimation of the health care expenditure from the dynamic model Dependent variable: expenditure

\begin{tabular}{|c|c|c|c|c|c|c|}
\hline \multirow{2}{*}{ Variable / Specification } & \multicolumn{3}{|c|}{ PANEL A } & \multicolumn{3}{|c|}{ PANEL B } \\
\hline & (i) & (ii) & (iii) & (i) & (ii) & (iii) \\
\hline $\begin{array}{l}\text { expenditure }_{\mathrm{t}-1} \\
\text { income } \\
\text { dependency } \\
\text { public share } \\
\text { technology }(\mathrm{x} 10)\end{array}$ & $\begin{array}{r}0.83^{* * *} \\
(0.02)^{* * *} \\
0.18^{* * *} \\
(0.03)\end{array}$ & $\begin{array}{r}0.82^{* * *} \\
(0.02) \\
0.20 \\
(0.03) \\
0.13 \\
(0.10)\end{array}$ & $\begin{array}{r}0.82^{* * *} \\
(0.03) \\
0.20^{* * *} \\
(0.03) \\
0.13 \\
(0.10) \\
0.01 \\
(0.10)\end{array}$ & $\begin{array}{r}0.80^{* * *} \\
(0.02) \\
0.17^{* * *} \\
(0.04)\end{array}$ & $\begin{array}{r}0.80^{* * *} \\
(0.02) \\
0.17 \\
(0.05) \\
0.04 \\
(0.11)\end{array}$ & $\begin{array}{r}0.80^{* * *} \\
(0.02) \\
0.18^{* * *} \\
(0.05) \\
0.02 \\
(0.11) \\
0.06 \\
(0.10) \\
0.03 \\
(0.00)\end{array}$ \\
\hline Long-run elasticity ${ }^{\mathrm{a}}$ & ${ }^{1.07}{ }^{* * *}$ & $\begin{array}{l}1.11 \\
(0.05)\end{array}$ & $\begin{array}{l}1.12^{* * *} \\
(0.05)\end{array}$ & $\begin{array}{l}0.86^{* * *} \\
(0.12)\end{array}$ & $\begin{array}{l}0.88^{* * *} \\
(0.14)\end{array}$ & $\begin{array}{l}0^{0.87^{* * *}} \\
(0.14)\end{array}$ \\
\hline $\begin{array}{l}\text { Arellano-Bond test for AR(1) in first differences } \\
p \text {-value } \\
\text { Arellano-Bond test for AR(2) in first differences } \\
p \text {-value }\end{array}$ & $\begin{array}{r}-2.58 \\
0.01 \\
-2.19 \\
0.03\end{array}$ & $\begin{array}{r}-2.56 \\
0.01 \\
-2.19 \\
0.03\end{array}$ & $\begin{array}{r}-2.56 \\
0.01 \\
-2.20 \\
0.03\end{array}$ & $\begin{array}{r}-2.56 \\
0.01 \\
-2.20 \\
0.03\end{array}$ & $\begin{array}{r}-2.56 \\
0.01 \\
-2.20 \\
0.03\end{array}$ & $\begin{array}{r}-2.56 \\
0.01 \\
-2.17 \\
0.03\end{array}$ \\
\hline
\end{tabular}

Notes: Robust standard errors are reported in brackets. ${ }^{a}$ Standard errors calculated from Equation 4 using the delta method. ${ }^{* * *},{ }^{* *}$, and ${ }^{*}$ denote significant at $1 \%, 5 \%$, and $10 \%$. Number of observations: 532 . Coefficient on income yields the short-run elasticity. 
Table 6. Sensitivity to alternative specifications

Dependent variable: expenditure

\begin{tabular}{|c|c|c|c|c|c|c|}
\hline & & \multicolumn{3}{|c|}{ Short-run elasticity } & \multicolumn{2}{|c|}{ Long-run elasticity $^{a}$} \\
\hline & & Linear & PANEL A & PANEL B & PANEL A & PANEL B \\
\hline \multirow{2}{*}{ Full set of sample countries } & \multirow{2}{*}{$1971-2009$} & 0.94 & 0.20 & 0.18 & 1.12 & 0.87 \\
\hline & & $(0.06)$ & $(0.03)$ & $(0.05)$ & $(0.05)$ & $(0.14)$ \\
\hline \multirow{4}{*}{ Subperiod of time } & \multirow{3}{*}{$1971-1990$} & 1.24 & 0.30 & 0.47 & 1.21 & 1.55 \\
\hline & & $(0.07)$ & $(0.07)$ & $(0.07)$ & $(0.08)$ & $(0.14)$ \\
\hline & & $1.03^{* * *}$ & $0.29^{* * *}$ & $0.29^{* * *}$ & $1.41^{* * *}$ & $1.36^{* * *}$ \\
\hline & 1991-2009 & $(0.07)$ & $(0.06)$ & $(0.07)$ & $(0.05)$ & $(0.27)$ \\
\hline \multirow{4}{*}{ Subsample of countries } & \multirow{3}{*}{ Upper } & 1.09 & 0.20 & 0.18 & 1.12 & 0.99 \\
\hline & & $(0.09)$ & $(0.06)$ & $(0.07)$ & $(0.08)$ & $(0.19)$ \\
\hline & & $0.86^{* * *}$ & $0.16^{* * *}$ & $0.12^{* * *}$ & $1.06^{* * *}$ & $0.62^{* * *}$ \\
\hline & Lower & $(0.09)$ & $(0.03)$ & $(0.03)$ & $(0.07)$ & $(0.07)$ \\
\hline
\end{tabular}

Notes: Upper-group (higher health expenditure and income initial levels): Australia, Austria, Canada, Finland, Iceland, New Zealand, Sweden, UK and US; lowergroup (lower health expenditure and income initial levels): Ireland, Japan, Norway, Portugal and Spain. Robust standard errors are reported in brackets. ${ }^{\text {a Standard }}$ errors calculated from Equation 4 using the delta method. ${ }^{* * *},{ }^{* *}$, and ${ }^{*}$ denote significant at $1 \%, 5 \%$, and $10 \%$. Panel $\mathrm{A}$, when the technology variable is omitted, whereas it is included in Panel B. 
Fig. 2. Recursive estimates of the income elasticity for the sample countries

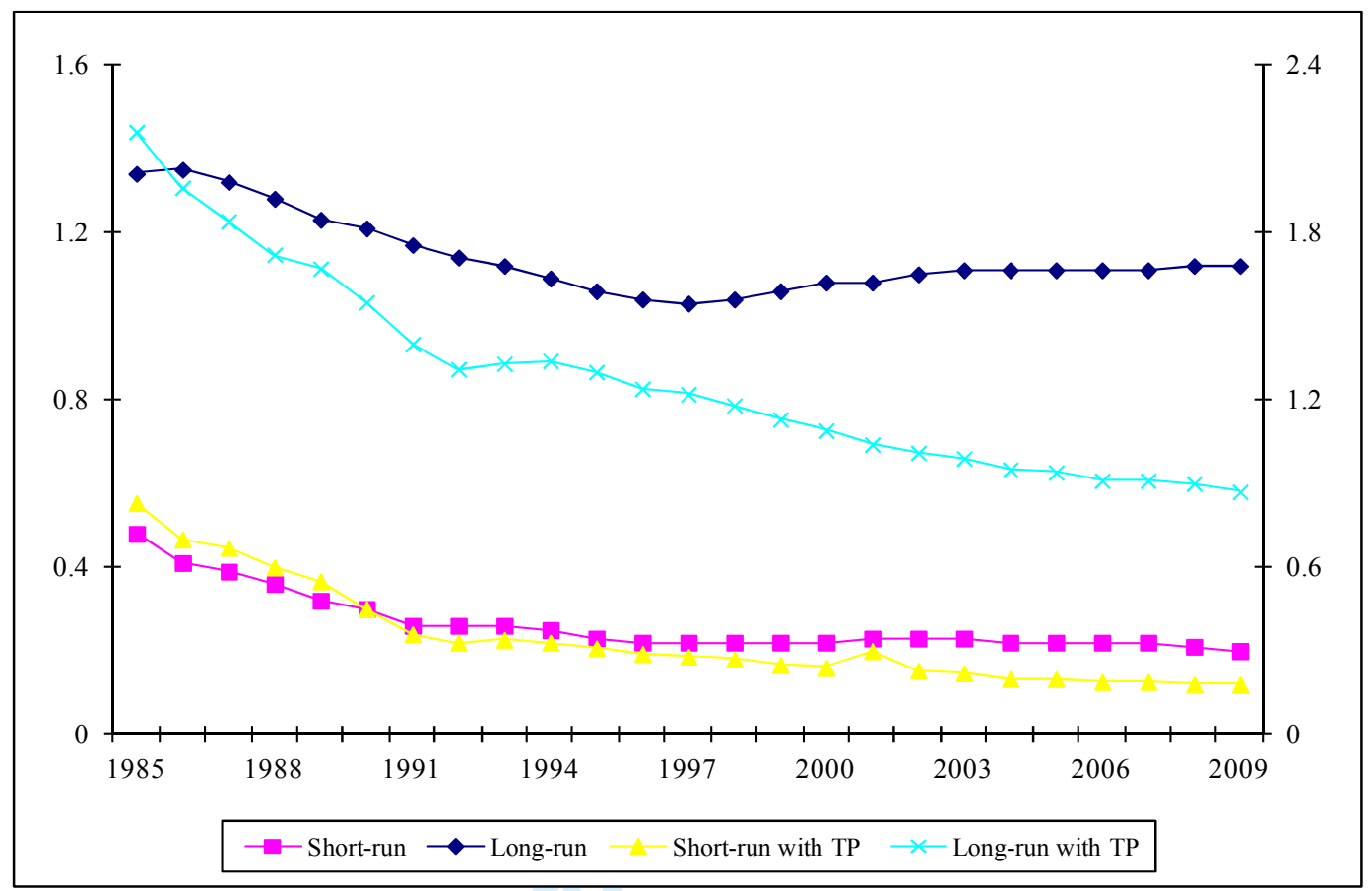

Notes: Short- and long-run elasticity without technical progress, left scale; short- and long-run elasticity considering technical progress, right scale. 
1

2

3

4

5

6

7

8

9

10

11

12

13

14

15

16

17

18

19

20

21

22

23

24

25

26

27

28

29

30

31

32

33

34

35

36

37

38

39

40

41

42

43

44

45

46

47

48

49

50

51

52

53

54

55

56

57

58

59

60

Fig. 3. Recursive estimates of the income elasticity for two clusters of countries considering technical progress

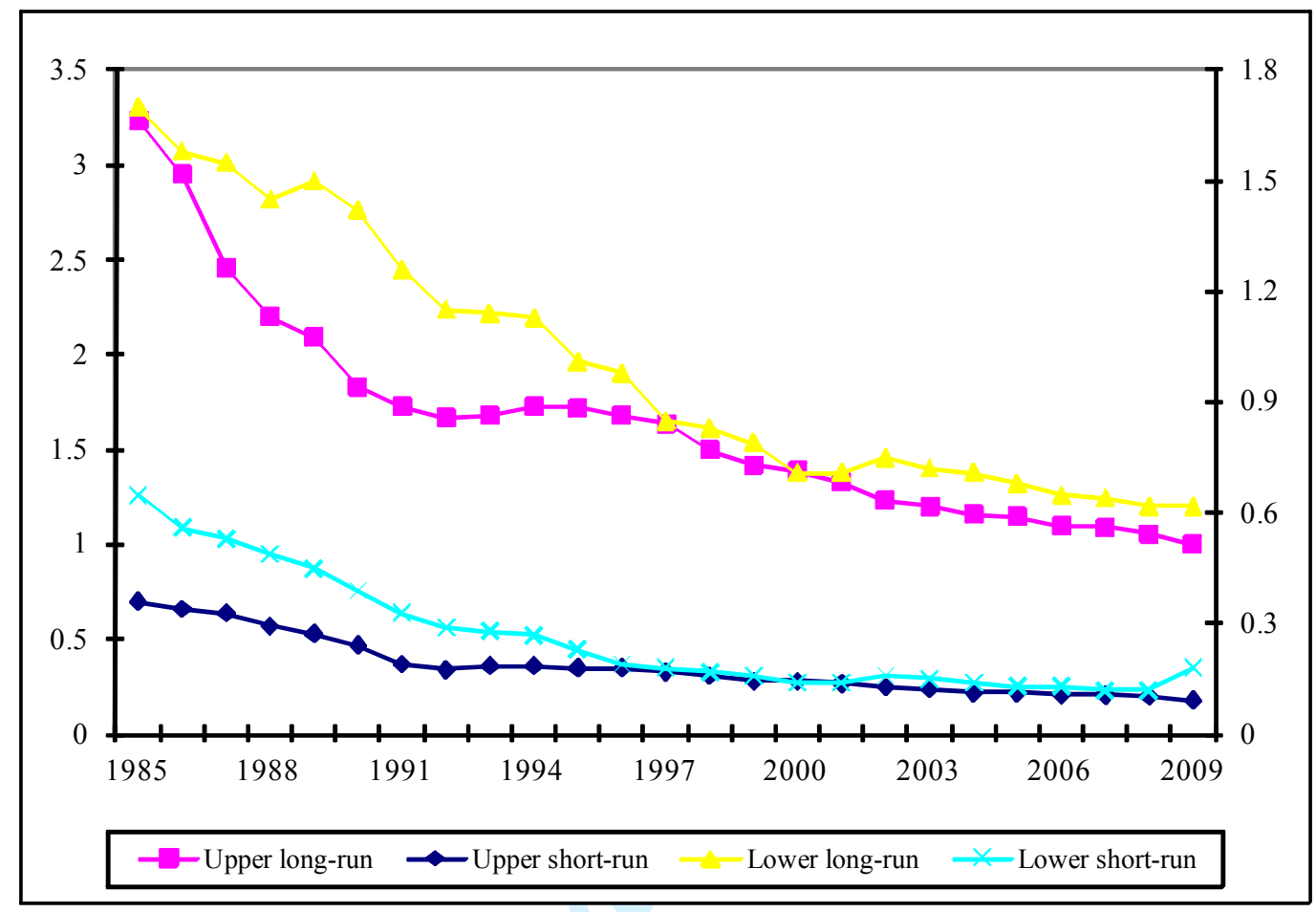

Notes: Upper and lower long-run left scale; upper and lower short-run right scale. 
Fig. 4 Sigma-convergence of health spending in OECD countries

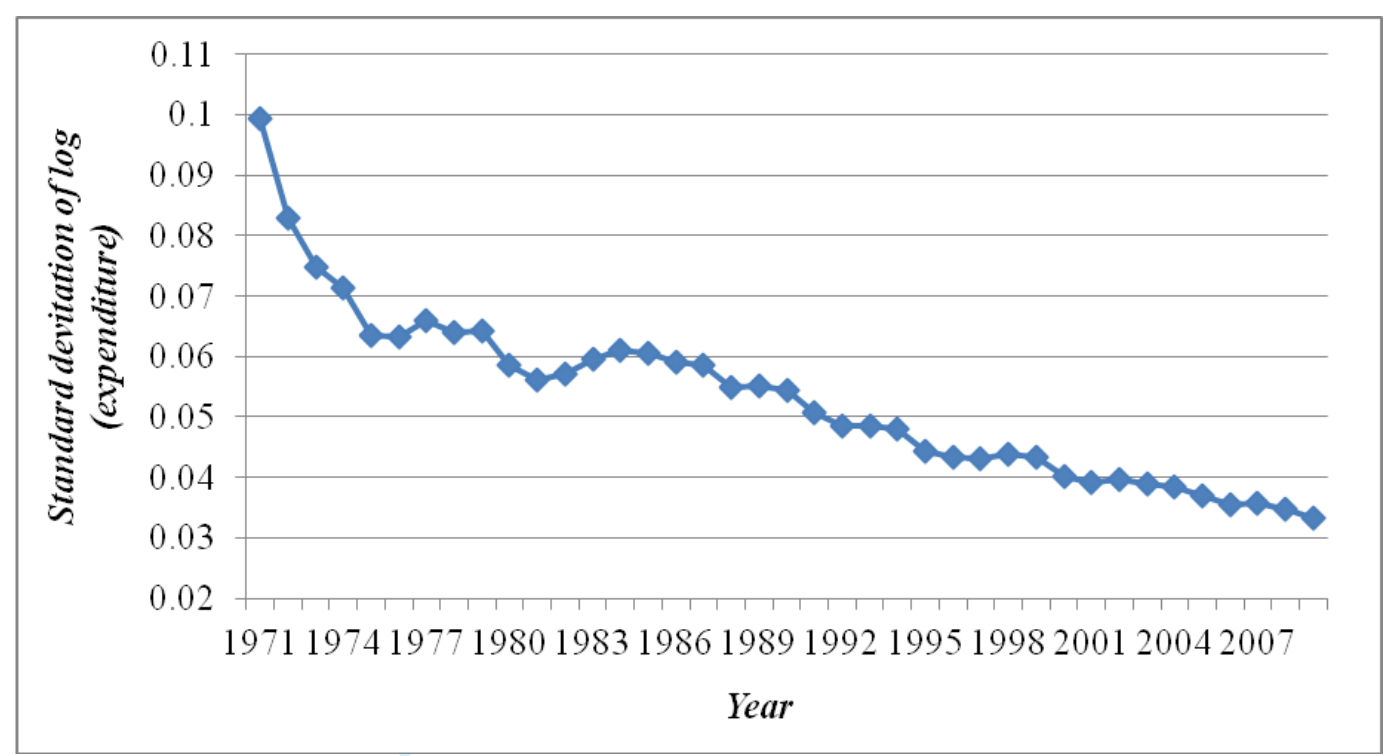

Editorial Office, Dept of Economics, Warwick University, Coventry CV4 7AL, UK34 
1

2

3

4

5

6

7

8

9

10

11

12

13

14

15

16

17

18

19

20

21

22

23

24

25

26

27

28

29

30

31

32

33

34

35

36

37

38

39

40

41

42

43

44

45

46

47

48

49

50

51

52

53

54

55

56

57

58

59

60

Fig. 5. Beta-convergence in OECD countries, 1971-2009

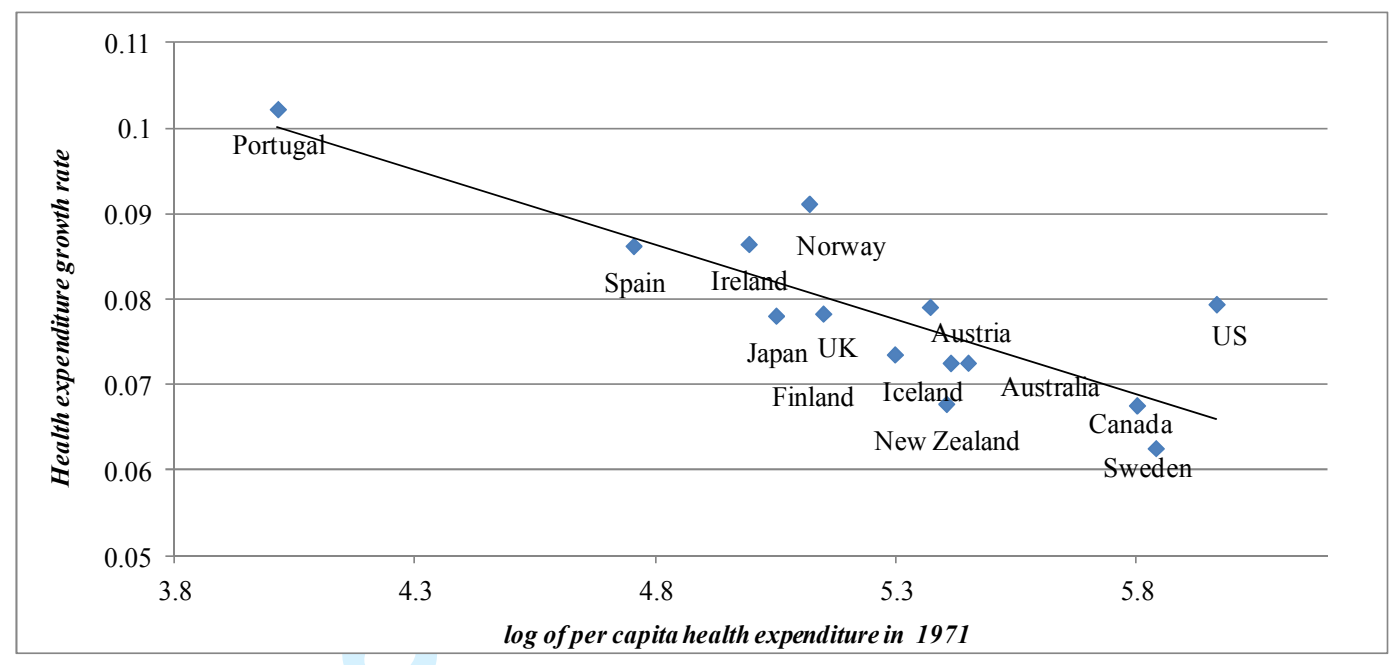

Editorial Office, Dept of Economics, Warwick University, Coventry CV4 7AL, UK 35 


\section{Appendix}

Fig. A.1. Per capita health expenditure by country (\$US PPP)

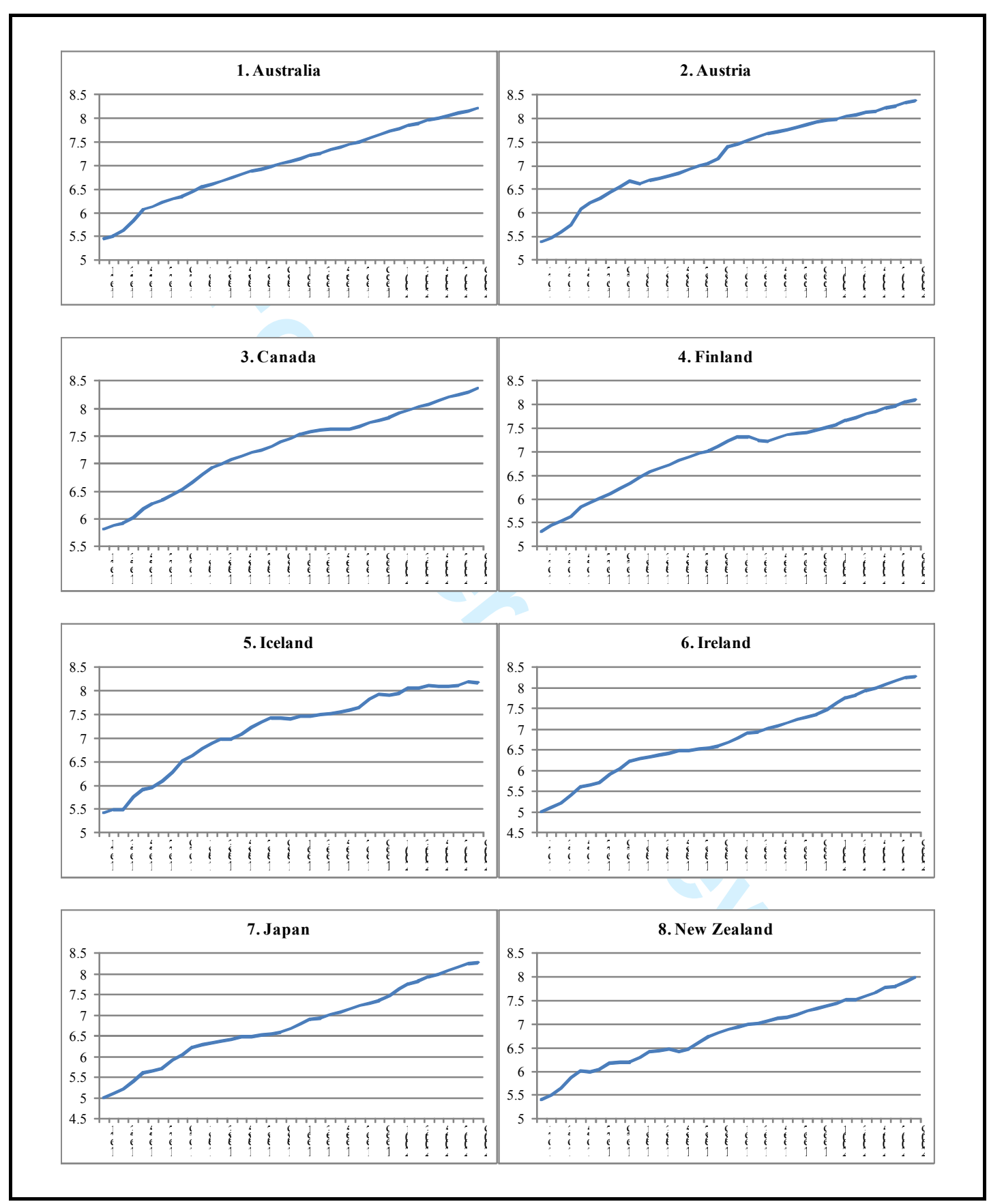

Editorial Office, Dept of Economics, Warwick University, Coventry CV4 7AL, UK 37 

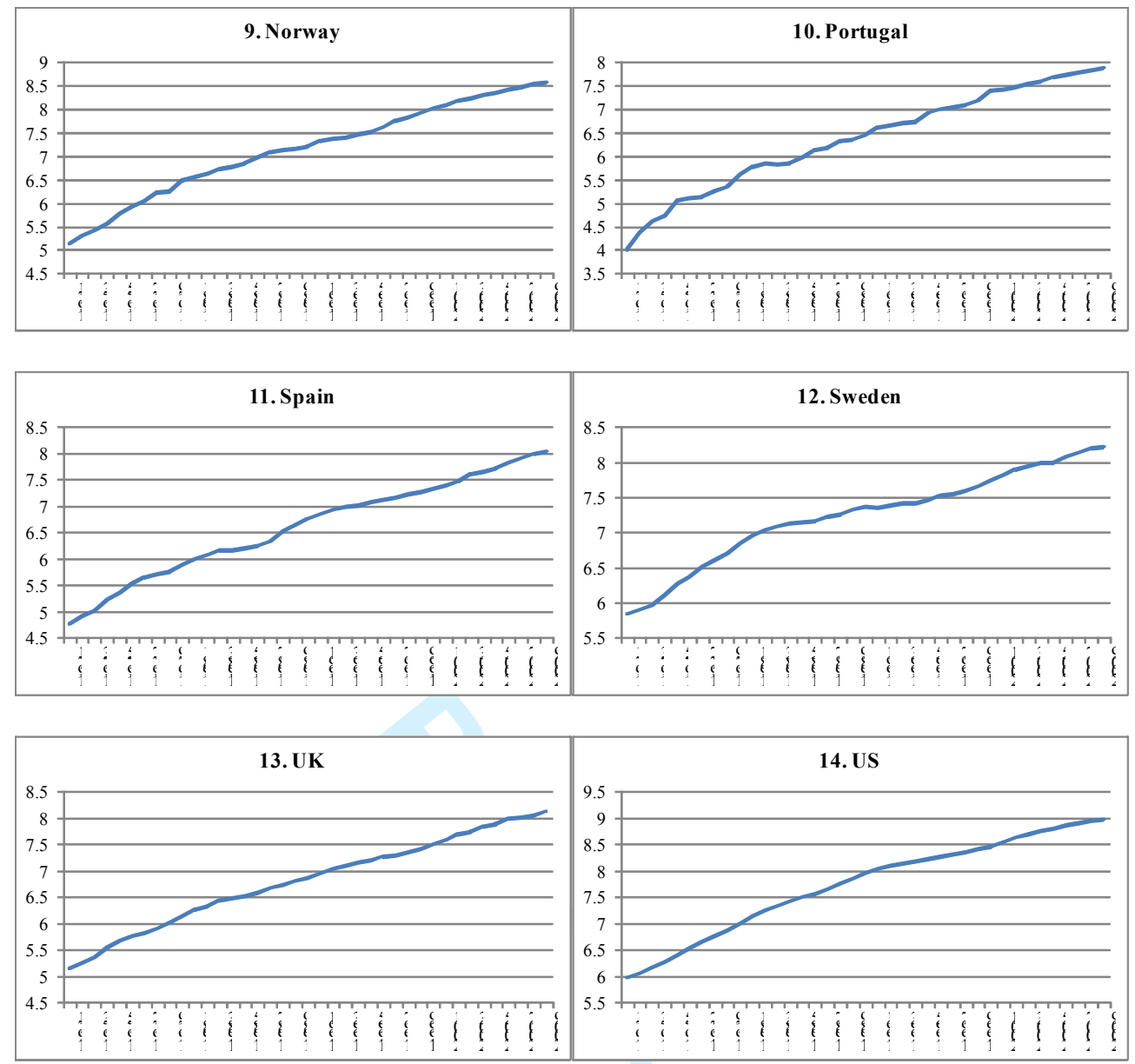

Source: Authors' elaboration based in OECD Health Data (2012).

Editorial Office, Dept of Economics, Warwick University, Coventry CV4 7AL, UK 38 
Table A.1. Determinants of health care expenditure: Econometric estimates of subperiods for specification (iii). Dependent variable: expenditure

\begin{tabular}{|c|c|c|c|c|c|c|}
\hline & & \multicolumn{3}{|c|}{ Short-run elasticity } & \multicolumn{2}{|c|}{ Long-run elasticity $^{\mathrm{a}}$} \\
\hline & & Linear & PANEL A & PANEL B & PANEL A & PANEL B \\
\hline \multirow{2}{*}{ Full set of observations } & \multirow{2}{*}{$1971-2009$} & 0.94 & 0.20 & 0.18 & 1.12 & 0.87 \\
\hline & & $(0.06)$ & $(0.03)$ & $(0.05)$ & $(0.05)$ & $(0.14)$ \\
\hline \multirow{8}{*}{ Subperiod of time } & \multirow{2}{*}{$1971-1975$} & 1.64 & $0.58^{* * *}$ & 0.44 & $2.46^{* * *}$ & 1.95 \\
\hline & & $(0.11)$ & $(0.16)$ & $(0.28)$ & $(0.61)$ & $(0.52)$ \\
\hline & \multirow{2}{*}{ 1976-1991 } & 1.12 & $0.29^{* * *}$ & $0.33^{* * *}$ & $1.09^{* * *}$ & 1.22 \\
\hline & & $(0.09)$ & $(0.06)$ & $(0.09)$ & $(0.12)$ & $(0.23)$ \\
\hline & \multirow{2}{*}{$1992-2001$} & $1.30^{* * *}$ & $0.46^{* * * *}$ & $0.46^{* * *}$ & $1.39^{* * *}$ & 1.43 \\
\hline & & $(0.08)$ & $(0.14)$ & $(0.12)$ & $(0.07)$ & $(0.27)$ \\
\hline & \multirow{2}{*}{$2002-2009$} & $1.06^{* * *}$ & $0.20^{* * *}$ & $0.19^{* * *}$ & $1.18^{* * *}$ & 1.05 \\
\hline & & $(0.07)$ & $(0.06)$ & $(0.06)$ & $(0.12)$ & $(0.38)$ \\
\hline
\end{tabular}

Notes: Robust standard errors are reported in brackets. ${ }^{a}$ Standard errors calculated from Equation 4 using the delta method. ${ }^{* * *},{ }^{* *}$, and ${ }^{*}$ denote significant at $1 \%, 5 \%$, and 10\%. Panel A, when the technology variable is omitted, whereas it is included in Panel B. 